\title{
Pengembangan Pendidikan Lingkungan Hidup Melalui Program Adiwiyata (Studi di Kota Surabaya)
}

\section{Environmental Education Development through Adiwiyata Program (Study in Surabaya City)}

\author{
Yulia Indahri \\ yulia.indahri@dpr.go.id \\ Pusat Penelitian, Badan Keahlian DPR RI \\ Jl. Jenderal Gatot Subroto, Senayan, Jakarta, 10270
}

Naskah diterima: 5 September 2020 | Naskah direvisi: 12 Oktober 2020 | Naskah diterbitkan: 31 Desember 2020

\begin{abstract}
Environmental education (EE) is an integration of environmental understanding with formal or informal education. EE is expected to help students gain understanding on the awareness and knowledge about the environment to further shape student attitudes. From these understanding, skills and abilities will emerge so that students can actively participate and become agents in solving environmental problems. The concept of EE itself can be traced back to the $18^{\text {th }}$ century, although globally, those engaged in the environmental sector began to strive to develop a more measurable EE concept since the 1970s. The legal basis also varies, with application models that adapt to each distinctive environment. Adiwiyata is a form of EE managed by the government through the integration of two important ministries, namely the ministry that deals with environmental issues and the ministry that deals with education. This study was intended to find out whether Adiwiyata was in accordance with the EE concept that was agreed upon globally. In particular, the implementation of the Adiwiyata Program in Surabaya City is the focus of this paper based on the results of research on the environment in 2019 which have been published. The environmental awareness of Adiwiyata School in Surabaya City is quite high and the concept developed by the Surabaya City Government is very solid that involves all parties.
\end{abstract}

Keywords: Adiwiyata; environmental education; Surabaya

Abstrak: Pendidikan lingkungan hidup (PLH) merupakan pengintegrasian pemahaman lingkungan hidup dengan pendidikan formal atau pendidikan informal. PLH diharapkan dapat membantu siswa memperoleh kesadaran dan pengetahuan mengenai lingkungan hidup untuk selanjutnya dapat membentuk sikap siswa. Dari pemahaman tersebut akan muncul keterampilan dan kecakapan sehingga siswa dapat berpartisipasi aktif dan menjadi agen dalam memecahkan masalah lingkungan. Konsep PLH sendiri dapat ditelusuri sampai abad ke-18, walaupun secara global, mereka yang bergerak di bidang lingkungan hidup mulai berupaya untuk menyusun konsep PLH yang lebih terukur sejak tahun 1970-an. Dasar hukumnya pun beragam, dengan model penerapan yang menyesuaikan dengan lingkungan masing-masing. Adiwiyata merupakan salah satu bentuk PLH yang dikelola pemerintah dengan mengintegrasikan dua kementerian penting, yaitu kementerian yang menangani masalah lingkungan hidup dan kementerian yang menangani pendidikan. Kajian ini 
dimaksudkan untuk mengetahui apakah Adiwiyata sudah sesuai dengan konsep PLH yang disepakati secara global. Secara khusus, pelaksanaan Program Adiwiyata di Kota Surabaya menjadi fokus dari tulisan ini berdasarkan hasil penelitian tentang lingkungan di tahun 2019 yang telah dibukukan. Kesadaran lingkungan Sekolah Adiwiyata di Kota Surabaya sudah cukup tinggi dan konsep yang dikembangkan oleh Pemerintah Kota (Pemkot) Surabaya sangat solid dengan melibatkan semua pihak.

Kata Kunci: Adiwiyata; pendidikan lingkungan hidup; Surabaya

\section{Pendahuluan}

Pelaksanaan konsep pendidikan lingkungan hidup (PLH) dapat ditelusuri sejak abad ke-18 ketika Jean-Jacques Rousseau dan Louis Agassiz (satu dekade kemudian) memperkenalkan pendidikan tentang alam (nature study) kepada masyarakat umum (Pruitt, 2019: 201). Rousseau melalui bukunya Emile: or, On Education dan Agassiz melalui praktik langsung dengan siswa merupakan dua tokoh penting yang membantu meletakkan dasar PLH di akhir abad ke-19 dan awal abad ke-20. Sejak saat itu, selain nature study, PLH mulai muncul dengan berbagai nama, seperti pendidikan konservasi (conservation education), environmentalism (terkait dengan upaya menangani polusi), dan terakhir environmental education atau PLH (Gough \& Gough, 2010: 340).

PLH merupakan proses pembelajaran dengan memberikan perspektif pengetahuan dan kesadaran lingkungan secara menyeluruh yang tidak hanya diperuntukkan bagi pendidikan formal, tetapi juga informal (Pruitt, 2019: 119). PLH merupakan sarana penting dalam menghasilkan sumber daya manusia yang dapat melaksanakan prinsip pembangunan berkelanjutan (Yustina, 2006: 55). Di sekolah, salah satu bentuk PLH adalah pengintegrasian pemahaman lingkungan hidup dengan kurikulum. Adiwiyata merupakan program PLH yang diinisiasi oleh Kementerian Lingkungan Hidup dan Kehutanan (KLHK) dan berkoordinasi dengan Kementerian Pendidikan dan Kebudayaan (Kemendikbud). Empat komponen Adiwiyata adalah kebijakan, kurikulum, partisipasi, dan sarana prasarana (sarpras).
Melihat cukup komprehensifnya komponen Adiwiyata, maka kajian ini dimaksudkan untuk mengetahui apakah pelaksanaan Program Adiwiyata di Kota Surabaya sudah sesuai dengan konsep PLH yang disepakati secara global? Secara khusus, pelaksanaan Program Adiwiyata di Kota Surabaya menjadi fokus dari tulisan ini, karena berdasarkan penelitian yang telah dilakukan diketahui bahwa banyak sekolah di Kota Surabaya pada khususnya dan Jawa Timur pada umumnya yang mendapatkan penghargaan Adiwiyata, baik Nasional maupun Mandiri (Qodriyatun, 2019: 53).

Data dalam kajian selain berasal dari studi literatur media massa dan karya tulis ilmiah juga mengutip hasil wawancara dengan Dinas Lingkungan Hidup (DLH) Kota Surabaya pada saat penulis menjadi anggota kelompok penelitian tentang "Kebijakan Pembatasan Plastik Sekali Pakai dan Implikasinya terhadap Industri dan Masyarakat" di tahun 2019. Hasil penelitian tersebut juga telah dipublikasikan dalam bentuk karya tulis ilmiah dengan judul Sampah Plastik dan Implikasi Kebijakan Pembatasan Plastik Sekali Pakai terhadap Industri dan Masyarakat. Kesadaran lingkungan di Sekolah Adiwiyata di Kota Surabaya sudah cukup tinggi dan konsep yang dikembangkan oleh Pemerintah Kota (Pemkot) Surabaya sangat solid dengan melibatkan semua pihak.

\section{Sejarah Pendidikan Lingkungan Hidup}

Secara global, pemahaman akan arti penting PLH dimulai sejak tahun 1970-an. Dokumen utama yang 
membahas mengenai PLH adalah Deklarasi Stockholm, 5-16 Juni 1972, yang merupakan hasil dari Konferensi PBB tentang Lingkungan Hidup (The Conference on the Human Environment) (Sohn, 1973: 1). Selanjutnya hari pertama pelaksanaan konferensi tersebut, yaitu tanggal 5 Juni, sejak tahun 1974 disepakati sebagai Hari Lingkungan Hidup Sedunia yang terus diperingati hingga saat ini (Sand, 2015: xv).

Hasil lain dari Konferensi adalah dibentuknya United Nations Environment Programme (UNEP), organisasi PBB di bidang lingkungan hidup (Ivanova, 2010: 31). UNEP diberi mandat untuk menetapkan agenda lingkungan global, mempromosikan implementasi yang koheren dari dimensi lingkungan dengan berpedoman pada pembangunan berkelanjutan sistem PBB. Pembentukan UNEP penting pada masanya karena di akhir 1960-an dan awal 1970-an, pemahaman tentang lingkungan masih sangat terbatas.

Deklarasi Stockholm melihat bahwa sebagian besar masalah lingkungan di negara berkembang disebabkan oleh keterbelakangan, yang dicirikan dengan kurangnya sandang, pangan, papan, serta keterbatasan akses pendidikan, kesehatan, dan sanitasi (UNEP, 1972: 1). Secara khusus, pada Prinsip ke-19, deklarasi mengharapkan pemerintah dan masyarakat untuk berupaya melestarikan dan memperbaiki lingkungan hidup melalui pendidikan dengan tetap memperhatikan kelompok masyarakat prasejahtera (UNEP, 1972: 3).

Selanjutnya UNEP pada Januari 1975 bersama dengan United Nations Educational, Scientific and Cultural Organization (UNESCO) meluncurkan Program Pendidikan Lingkungan Internasional (International Environmental Education Program, IEEP) (Mohamed, Kidundo, \& Tagelseed, 2006: 3). Tujuan peluncuran Program ini adalah untuk memfasilitasi koordinasi serta perencanaan program dan kegiatan bersama di bidang PLH. Kegiatan dimaksud dapat berbentuk pertukaran ide, penelitian, evaluasi metode $\mathrm{PLH}$, serta pelatihan dengan UNESCO/ UNEP sebagai konsultannya (Bhagwut, 1997: 80).

Kesempatan selanjutnya yang secara khusus mengangkat tema PLH adalah workshop di Belgrade, Yugoslavia (13-22 Oktober 1975). Hasil workshop adalah sebuah Piagam yang mendorong dilakukannya reformasi sistem pendidikan dan penataan ulang prioritas nasional dan regional yang menyertakan pelestarian lingkungan. Workshop ini merupakan kerja sama antara UNESCO dan UNEP, dan menghasilkan lebih dari 100 rekomendasi terkait dengan 11 area utama yang berkaitan dengan tema workshop (Čeřovský, 2009: 76). Selanjutnya hasil workshop dapat dijadikan pedoman dasar penerapan PLH.

Harapan dari workshop ini, PLH sebagai satu kesatuan merupakan proses sepanjang hayat di dalam dan di luar sekolah dengan pendekatan interdisipliner. Pendekatan yang melibatkan partisipasi aktif dalam mencegah dan memecahkan masalah lokal dan global, yang diharapkan dapat membantu perubahan sikap dan mindset masyarakat dalam melindungi dan memelihara lingkungan hidup. Pendidikan dapat menumbuhkan kesadaran pentingnya menjaga kelestarian lingkungan melalui integrasi pendidikan nilai yang dapat menumbuhkan karakter sadar lingkungan melalui pembelajaran. Selanjutnya sekolah dapat berperan sebagai agen perubahan mindset masyarakat untuk sadar lingkungan.

Sebelum memasuki pergantian abad, masih ada beberapa upaya global dalam mendorong kesadaran lingkungan yang terkait dengan PLH, dengan salah satu pertemuan penting di Tbilisi, Georgia, USSR, Oktober 1977 (Eneji, Akpo, \& Etim, 2017: 117). Konferensi antar-pemerintah mengenai PLH (Intergovernmental Conference on Environmental Education) di 
Georgia ini menekankan pada pelestarian dan perbaikan lingkungan hidup dunia dan mencari kerangka kerja serta pedoman PLH. Deklarasi Tbilisi yang merupakan dokumen hasil konferensi ini menetapkan pedoman, tujuan, dan karakteristik dari PLH.

Upaya global berikutnya yang berhubungan langsung dengan PLH adalah Tujuan Pembangunan Milenium (Millennium Development Goals, MDGs) yang berlangsung tahun 2005-2015. PLH mendapatkan perhatian khusus dengan adanya Dekade Pendidikan untuk Pembangunan Berkelanjutan (Decade of Education for Sustainable Development, DESD) yang beriringan pelaksanaannya dengan MDGs. DESD diluncurkan oleh PBB untuk mengintegrasikan prinsip, nilai, dan praktik pembangunan berkelanjutan ke dalam pendidikan. Laporan resmi PBB mengenai DESD sudah disampaikan menjelang penghujung dekade (UNESCO, 2014: 22).

Tabel 1.

\section{Contoh Peraturan, Kebijakan, dan} Standar Kurikulum PLH

\begin{tabular}{ll}
$\begin{array}{c}\text { Negara/ } \\
\text { Bagian } \\
\text { Negara }\end{array}$ & Peraturan/Kebijakan/ Standar \\
\hline Brazil & Konstitusi Brasil (1988) \\
& $\begin{array}{l}\text { Kebijakan nasional bidang } \\
\text { lingkungan (1981) } \\
\text { - Kebijakan nasional PLH (1999) }\end{array}$ \\
\hline India & MA India menetapkan PLH \\
& bersifat wajib (1991) \\
& Kebijakan pemerintah untuk \\
& mengarusutamakan PLH (2003) \\
\hline Jepang & $\begin{array}{l}\text { Revisi undang-undang mengenai } \\
\text { lingkungan (2011) }\end{array}$ \\
\hline Kamboja & Undang-undang mengenai \\
& pendidikan (2007) \\
\hline Kazakhstan & Tata tertib lingkungan (2007) \\
\hline Swedia & $\begin{array}{l}\text { Undang-undang mengenai } \\
\text { pendidikan tinggi (1992) }\end{array}$ \\
\hline
\end{tabular}

Sumber: UNESCO, 2014: 55
Laporan UNESCO tersebut menyampaikan beberapa contoh bentuk peraturan, kebijakan, dan standar kurikulum PLH yang diterapkan oleh negara atau bagian negara, seperti dapat dilihat di Tabel 1.

Dari Tabel 1 dapat dipahami bahwa model penerapan PLH dapat dimulai dari sisi manapun. Konstitusi negara yang merupakan peraturan tertinggi dapat menjadi payung utama, dan di sisi yang lain tata tertib pun dapat dimanfaatkan untuk penerapan yang lebih teknis. Undang-undang bisa memasukkan hal lain -contohnya pendidikan moral dan pendidikan kewarganegaraan- sebagai bagian dari PLH seperti ditemui di Kamboja. Tata tertib di Kazakhstan mengenai PLH dimaksudkan untuk meningkatkan kesadaran lingkungan dan sikap positif masyarakat berdasarkan undang-undang yang disusun dengan memperhatikan lingkungan (ecolegislation) (UNESCO, 2014: 55).

Selanjutnya, pendidikan secara umum adalah tujuan keempat dari Tujuan Pembangunan Berkelanjutan (Sustainable Development Goals, SDGs) yang merupakan komitemen lanjutan dari MDGs. Tujuan keempat SDGs ingin memastikan pendidikan berkualitas yang inklusif dan adil melalui promosi kesempatan belajar sepanjang hayat untuk semua (UN, 2015: 19). Berbeda dengan MDGs yang sifatnya top down, maka SDGs dianggap lebih mengakar karena sifat pelaksanaannya yang bottom up (Marco, Mindt, \& Gardiner, 2017).

Tujuan keempat SDGs sebenarnya saling silang dengan semua tujuan SDGs. Pendidikan merupakan kunci dari berbagai tujuan, dengan beragam jenisnya, mulai dari pendidikan untuk pembangunan berkelanjutan, pendidikan lingkungan, pendidikan untuk perdamaian, pendidikan kejuruan, bahkan juga pendidikan tinggi (Mishra, 2017: 5). SDGs dengan muatan PLH telah menjadi komitmen dan tanggung jawab bersama masyarakat dunia untuk menyelamatkan bumi dari kerusakan 
dan kehancuran akibat pembangunan yang tidak memperhatikan kelestarian lingkungan. UNESCO telah mengimbau semua negara anggotanya untuk melaksanakan PLH yang diintegrasikan ke dalam kurikulum pendidikan lingkungan secara umum (Jayadinata, 2017: 460).

Mengacu pada Deklarasi Tbilisi, ada lima hal yang menjadi tujuan PLH bagi siswa, yaitu kesadaran, pengetahuan, sikap, keterampilan, dan partisipasi. PLH diharapkan dapat membantu siswa memperoleh kesadaran dan pengetahuan mengenai lingkungan hidup untuk selanjutnya dapat membentuk sikap siswa. Dari pemahaman tersebut akan muncul keterampilan dan kecakapan sehingga siswa dapat berpartisipasi aktif dalam memecahkan masalah lingkungan. Selain itu, ada tiga pilar pendidikan lingkungan yang dapat diadaptasi dari hasil pengembangan PLH oleh UNESCO/UNEP, yaitu pendidikan tentang lingkungan, pendidikan di/dari/melalui lingkungan, dan pendidikan untuk lingkungan. Halhal tersebut di atas diperlukan agar kita dapat menilai secara objektif sejauh mana implementasi PLH di Indonesia.

Di Indonesia, kewajiban masyarakat dalam pelindungan dan pengelolaan lingkungan hidup diatur dalam UndangUndang Nomor 32 Tahun 2009 tentang Perlindungan dan Pengelolaan Lingkungan Hidup (UU Lingkungan Hidup). Pasal 67 mewajibkan masyarakat untuk memelihara kelestarian fungsi lingkungan hidup serta pengendalian pencemaran dan/atau kerusakan lingkungan hidup. Sebelumnya, di Pasal 65 telah diatur juga bahwa setiap orang berhak -di antaranya- mendapatkan PLH dalam memenuhi hak atas lingkungan hidup yang baik dan sehat. Berangkat dari amanat UU Lingkungan Hidup, maka diperlukan upaya mendorong kegiatan sekolah di bidang lingkungan hidup secara terstruktur dengan pendekatan kebijakan dan kurikulum yang melibatkan seluruh pihak dan membawa dampak pada lingkungan secara keseluruhan.

\section{Gambaran Umum Pendidikan Lingkungan Hidup di Indonesia}

Jauh sebelum UU Lingkungan Hidup disahkan, PLH di Indonesia sudah diinisiasi oleh Institut Keguruan dan IImu Pendidikan (IKIP) Jakarta pada tahun 1975. Kurikulum 1975 mengintegrasikan PLH pada mata pelajaran yang relevan, untuk pendidikan dasar sampai dengan menengah berdasarkan S.K. Menteri Pendidikan dan Kebudayaan (Mendikbud) No. 008/U/1975. Inisiatif IKIP Jakarta tersebut merupakan tindak lanjut dari kegiatan Lokakarya tentang Lingkungan Hidup dan Pencemaran Lingkungan yang diselenggarakan di Jakarta pada tahun 1971 serta Seminar tentang Lingkungan Hidup yang diselenggarakan di Bandung pada tahun 1972 (Prasetyo \& Hariyanto, 2017: 196). Kurikulum 1975 merupakan kurikulum yang sarat beban. Akibatnya pendidikan lingkungan hidup tidak tergambar dengan jelas keterkaitannya. Materi PLH tersebar dalam mata pelajaran Agama, Pancasila, Pendidikan Jasmani dan Kesehatan, IImu Pengetahuan Sosial, dan IImu Pengetahuan Alam.

Di tahun 1977/1978, rintisan GarisGaris Besar Program Pengajaran (GBPP) Lingkungan Hidup diujicobakan di 15 SD di Jakarta. Pada tahun 1979 di bawah koordinasi Kantor Menteri Negara Pengawasan Pembangunan dan Lingkungan Hidup, dibentuk Pusat Studi Lingkungan (PSL) di berbagai PTN dan PTS, di mana pendidikan Analisis Mengenai Dampak Lingkungan (AMDAL) mulai dikembangkan. Sampai tahun 2010, jumlah PSL yang menjadi anggota Badan Koordinasi Pusat Studi Lingkungan (BKPSL) telah berkembang menjadi 101 PSL (KLH, 2011: 1).

\section{Direktorat Jenderal Pendidikan} Dasar dan Menengah, Departemen Pendidikan Nasional (Ditjen Dikdasmen Depdiknas) di tahun 1984 menetapkan bahwa penyampaian mata ajar tentang kependudukan dan lingkungan hidup secara terintegrasi dituangkan dalam 
Kurikulum 1984 dengan memasukkan materi kependudukan dan lingkungan hidup ke dalam semua mata pelajaran pada tingkat menengah umum dan kejuruan. Implementasi PLH yang lebih terarah dimulai sejak diterapkannya Kurikulum 1984 ini. Pada jenjang pendidikan dasar dan menengah, mata pelajaran kependudukan dan lingkungan hidup diajarkan dengan cara memasukkan masalah-masalah kependudukan dan lingkungan hidup ke dalam hampir semua mata pelajaran (Prasetyo \& Hariyanto, 2017: 202).

Pada 21 Mei 1996 disepakati kerja sama pertama antara Departemen Pendidikan dan Kebudayaan (Depdikbud) dan Kementerian Negara Lingkungan Hidup (KLH) untuk implementasi PLH melalui Keputusan Nomor 142/U/1996 dari Depdikbud dan Keputusan No 89/MENLH/5/1996 dari KLH tentang Pembinaan dan Pengembangan Pendidikan Lingkungan Hidup (Prasetyo \& Hariyanto, 2017: 201). Sejalan dengan itu, Ditjen Dikdasmen Depdikbud juga terus mendorong pengembangan dan pemantapan pelaksanaan PLH di sekolah-sekolah antara lain melalui penataran guru, penggalakan bulan bakti lingkungan, penyiapan Buku Pedoman Pelaksanaan Pendidikan Kependudukan dan Lingkungan Hidup (PKLH) untuk guru SD, SMP, SMA, dan SMK, serta Program Sekolah Asri (Sekarwinahyu, 2016: 1.13).

Departemen Pendidikan Nasional (Depdiknas) selanjutnya bekerja sama untuk pelatihan guru dengan Swisscontact melalui Vocational Education Development Center (VEDC) Malang pada tahun 19982000. Program kerja sama tersebut diwujudkan dalam bentuk pengembangan PLH untuk SMK melalui enam Pusat Pengembangan dan Penataran Guru (PPPG). Melalui program ini telah dilakukan pengembangan materi ajar PLH dan pelatihan lingkungan hidup tidak hanya bagi guru SMK, tetapi juga guru SD, SMP, dan SMA (KNIU, 2014: 30).
Selanjutnya di tahun 2004, tepatnya pada 19 Februari 2004, kebijakan PLH disepakati oleh empat kementerian/ lembaga negara, yaitu pada waktu itu KLH, Depdiknas, Departemen Agama, dan Departemen Dalam Negeri. Kebijakan ini menjadi dasar arahan bagi para pemangku kepentingan dalam pelaksanaan dan pengembangan PLH di Indonesia serta sebagai salah satu solusi dalam upaya meningkatkan pengetahuan dan pemahaman masyarakat terhadap pelestarian fungsi lingkungan hidup $(\mathrm{KLH}$, 2011: iii).

Upaya memajukan dan memperkenalkan materi PLH pada siswa, utamanya di pendidikan dasar, tidak hanya dilakukan melalui kurikulum nasional, tetapi juga kurikulum lokal atau muatan lokal. Kurikulum 2004 dan Kurikulum 2006 memang lebih maju dalam mengakomodasi aspek PLH dengan adanya alokasi waktu untuk implementasi kurikulum muatan lokal. Banyak daerah di Indonesia serta sekolah-sekolah mengisi kurikulum muatan lokal dengan materi PLH. Kerja sama antara dua kementerian di tahun 1996 selanjutnya diperbarui pada tahun 2005 dan 2010. Sebagai tindak lanjut dari kesepakatan tahun 2005, pada tanggal 21 Februari $2006 \mathrm{KLH}$ mengembangkan Program Adiwiyata pada jenjang pendidikan dasar dan menengah untuk mempercepat pengembangan PLH jalur pendidikan formal pada jenjang pendidikan dasar dan menengah (Ulul Albab, 2017: 259).

PLH melalui Adiwiyata oleh KLH didefinisikan sebagai upaya mengubah perilaku dan sikap yang dilakukan oleh berbagai pihak atau elemen masyarakat yang bertujuan untuk meningkatkan pengetahuan, keterampilan, dan kesadaran masyarakat tentang nilai-nilai lingkungan dan isu permasalahan lingkungan yang pada akhirnya dapat menggerakkan keselamatan lingkungan untuk kepentingan generasi sekarang dan yang akan datang. Hal ini juga mengacu kepada tujuan dari 
PLH itu sendiri yang telah disepakati secara global, yaitu pencapaian dalam bidang pengetahuan, bidang kesadaran, bidang perilaku, bidang keterampilan, dan bidang partisipasi sehingga PLH sekaligus dapat dijadikan sebagai alat yang efektif di dalam pembentukan karakter bagi generasi muda (KLH, 2011).

Target PLH antara lain minimal dapat membekali siswa dengan pengetahuan dan keterampilan yang cukup di bidang lingkungan hidup, yang selanjutnya akan melahirkan sikap dan perilaku yang sadar dan peduli serta berkomitmen di dalam melindungi serta mengelola lingkungan hidup secara arif dan bijaksana. Artinya Dokumen Tbilisi dan model PLH yang diusulkan oleh UNESCO/UNEP sudah mulai diterapkan di Indonesia. Sikap dan perilaku siswa yang berwawasan lingkungan akan mendorong terciptanya pola kehidupan masyarakat baru yang memiliki etika lingkungan hidup dan pada akhirnya dapat berimbas pada perbaikan kualitas hidup bersama.

\section{Program Adiwiyata}

Ada beberapa model PLH yang dapat ditemui di Indonesia. Seperti telah disampaikan di atas, untuk program DESD, Kemendikbud secara khusus membentuk Kelompok Kerja Program (Pokja) Pendidikan untuk Pembangunan yang Berkelanjutan. Hanya dua program yang dimunculkan dalam laporan Pokja, yaitu PLH di SMK melalui enam PPPG dan Adiwiyata (KNIU, 2014: 30). Hal ini dapat dipahami karena kedua program tersebut diinisiasi pemerintah dan memiliki struktur organisasi pelaksanaan yang lengkap. Dalam praktiknya, LSM sangat berperan dan sekolah yang dikelola masyarakat juga mulai menerapkan PLH dalam kurikulum pendidikannya (Greenschool, 2017: 1).

Kata Adiwiyata berasal dari bahasa Sansekerta. "Adi" bermakna besar, agung, baik, pengetahuan, sedangkan "wiyata" bermakna sebagai tempat di mana seseorang mendapat ilmu pengetahuan dan norma. Jadi, Adiwiyata bermakna tempat yang baik dan ideal untuk memperoleh ilmu pengetahuan, norma, etika yang menjadi dasar manusia menuju kesejahteraan hidup (Asaad, 2010: 62). Secara lebih terfokus, Peraturan Menteri Lingkungan Hidup Republik Indonesia Nomor 05 Tahun 2013 tentang Pedoman Pelaksanaan Program Adiwiyata (Permen Adiwiyata) mendefinisikan Program Adiwiyata sebagai program untuk mewujudkan sekolah peduli dan berbudaya lingkungan, artinya Adiwiyata merupakan bagian dari PLH.

Sebagai salah satu bentuk PLH, maka prinsip dasar dari Adiwiyata adalah edukatif, partisipatif, dan berkelanjutan. Edukatif dimaksudkan agar Adiwiyata dapat memberikan pengetahuan dan etika mengenai perlindungan dan pengelolaan lingkungan hidup dalam kehidupan. Partisipatif dimaksudkan agar komunitas yang ada di sekolah ikut terlibat baik dalam hal perencanaan, pelaksanaan, dan evaluasi sesuai tanggung jawab dan peran masing-masing. Selanjutnya, Adiwiyata diharapkan dapat dilaksanakan berkelanjutan, secara terencana dan terusmenerus (Asaad, 2010: 62).

Pada tahun 2006, di awal pelaksanaan Adiwiyata, program PLH rintisan ini melibatkan 10 sekolah di Pulau Jawa sebagai sekolah model dengan melibatkan perguruan tinggi dan LSM yang bergerak di bidang PLH. Sejak tahun 2006 sampai 2011 sekolah yang ikut partisipasi dalam program Adiwiyata hanya mencapai 1.351 sekolah dari 251.415 sekolah (SD, SMP, SMA, dan SMK). Sekolah yang memperoleh Adiwiyata Mandiri berjumlah 56 sekolah, Adiwiyata Nasional berjumlah 113 sekolah, calon Adiwiyata 103 sekolah. Total sekolah yang mendapat penghargaan Adiwiyata sampai 2011 mencapai 272 Sekolah (SD, SMP, SMA, SMK) seIndonesia yang sebarannya sebagian besar di Pulau Jawa, Bali dan ibu kota provinsi lainnya (KNIU, 2014: 31). 
Jumlah sekolah Adiwiyata Nasional meningkat menjadi 200 sekolah dan Adiwiyata Mandiri mencapai 67 sekolah di tahun 2012. Sebagai program tahunan, Adiwiyata di tahun 2013 mengalami peningkatan di mana sekolah yang mengikuti program Adiwiyata berjumlah 4.132 dari 33 provinsi dan sekolah yang mencapai kriteria nasional adalah 463 sekolah dari 19 provinsi serta 130 sekolah Adiwiyata Mandiri (KNIU, 2014: 31). Tabel 2 menyajikan perubahan jumlah penerima Penghargaan Adiwiyata, baik Adiwiyata Mandiri maupun Adiwiyata Nasional.

Tabel 2.

Jumlah Sekolah Penerima Adiwiyata, Tahun 2012-2018*

\begin{tabular}{lcccccc}
\hline \multicolumn{1}{c}{$\begin{array}{c}\text { Jenis } \\
\text { Adiwiyata }\end{array}$} & \multicolumn{6}{c}{ Tahun } \\
\cline { 2 - 7 } & $\mathbf{2 0 1 2}$ & $\mathbf{2 0 1 3}$ & $\mathbf{2 0 1 5}$ & $\mathbf{2 0 1 6}$ & $\mathbf{2 0 1 7}$ & $\mathbf{2 0 1 8}$ \\
\hline $\begin{array}{l}\text { Adiwiyata } \\
\text { Mandiri }\end{array}$ & 67 & 130 & 95 & 111 & 113 & 117 \\
\hline $\begin{array}{l}\text { Adiwiyata } \\
\text { Nasional }\end{array}$ & 200 & 463 & 548 & 489 & 423 & 279 \\
\hline Total & $\mathbf{2 7 6}$ & $\mathbf{5 9 3}$ & $\mathbf{6 4 3}$ & $\mathbf{6 0 0}$ & $\mathbf{5 3 6}$ & $\mathbf{3 9 6}$ \\
\hline
\end{tabular}

* Tanpa data untuk 2014

Sumber: KNIU, 2014: 31; KLHK, 2019: 408

Data di Tabel 2 memperlihatkan terjadinya peningkatan jumlah penerima Penghargaan Adiwiyata yang mencapai puncaknya di tahun 2015. Hal ini bukan berarti terjadi penurunan kualitas PLH, tetapi lebih karena KLHK melakukan terobosan lain untuk mengembangkan PLH. Selain Adiwiyata, KLHK sebagai kementerian yang ditugaskan mengoordinasikan pengelolaan lingkungan hidup juga melakukan program ecocampus, eco-school, dan eco-pesantren untuk memperluas cakupan PLH di jenjang pendidikan lain (Qodriyatun, 2019: vii).

Menurut Prasetyo dan Hariyanto (2017: 221), Adiwiyata merupakan salah satu wahana education for sustainable development, yang berada di bawah koordinasi dan tanggung jawab KLHK, dan merupakan program skala nasional yang dikelola dalam rangka mewujudkan pengembangan PLH. Komponen Adiwiyata yang menjadi sasaran penilaian dan harus menjadi kesatuan utuh dalam mencapai Sekolah Adiwiyata meliputi: (1) kebijakan sekolah yang berwawasan lingkungan; (2) pelaksanaan kurikulum yang berbasis lingkungan; (3) kegiatan lingkungan berbasis partisipatif; dan (4) pengelolaan sarpras sekolah yang ramah lingkungan. Komponen tersebut secara singkat disebut kebijakan, kurikulum, partisipatif, dan sarpras (KLH, 2013).

Pencapaian komponen Adiwiyata akan membawa dampak positif lain, seperti: (1) mendukung pencapaian standar kompetensi lulusan (SKL)/Kompetensi Inti/Kompetensi Dasar bagi setiap mata pelajaran di sekolah; (2) meningkatkan efisiensi penggunaan dana operasional sekolah melalui penghematan dan pengurangan konsumsi dari berbagai sumber daya dan energi; (3) menciptakan kebersamaan warga sekolah dan kondisi belajar mengajar yang lebih nyaman dan kondusif; (4) menjadi tempat pembelajaran tentang nilai-nilai pemeliharaan dan pengelolaan lingkungan hidup yang baik dan benar bagi warga sekolah dan masyarakat sekitar; dan (5) meningkatkan upaya perlindungan dan pengelolaan lingkungan hidup melalui kegiatan pengendalian pencemaran, pengendalian kerusakan, dan pelestarian fungsi lingkungan di sekolah.

Pedoman pelaksanaan Adiwiyata berdasarkan Permen Adiwiyata bertujuan untuk memberikan arah dan pedoman pelaksanaan Program Adiwiyata kepada seluruh unsur pelaksana, baik di tingkat pusat maupun daerah. Adiwiyata dapat diikuti lembaga pendidikan formal, mulai dari SD, SMP, sampai SMA dan SMK baik sekolah umum maupun madrasah, negeri maupun swasta (KLH, 2013).

Permen Adiwiyata juga menetapkan bahwa empat komponen Adiwiyata memiliki delapan standar yang dapat dijadikan pedoman penilaian. Komponen kebijakan berwawasan lingkungan memiliki 
standar dalam bentuk kurikulum serta rencana kegiatan dan anggaran sekolah yang memuat program dalam pelindungan dan pengelolaan lingkungan hidup. Komponen kurikulum berbasis lingkungan memiliki standar tenaga pendidik dan peserta didik yang terlibat dalam kegiatan pembelajaran tentang perlindungan dan pengelolaan lingkungan hidup. Komponen kegiatan lingkungan berbasis partisipatif memiliki standar kegiatan bagi warga sekolah dan kemitraan dengan pihak lain. Terakhir, komponen pengelolaan sarpras pendukung ramah lingkungan memiliki standar ketersediaan dan peningkatan kualitas pengelolaan sarpras yang ramah lingkungan (KLH, 2013).

Selanjutnya, Permen Adiwiyata juga menetapkan 33 implementasi kebijakan berwawasan lingkungan sebagai standar awal satu sekolah dapat dikatakan Sekolah Adiwiyata (KLH, 2013). Berdasarkan Permen Adiwiyata, telah ditetapkan tahapan seleksi yang harus dilalui sekolah yang ingin mendapatkan Penghargaan Adiwiyata. Tahapan tersebut dapat dilihat di Bagan 1.

\begin{tabular}{llc}
\hline \multicolumn{1}{c}{ Kriteria } & \multicolumn{1}{c}{ Pengelola } & Penghargaan \\
\hline & & ASEAN Eco School \\
Nilai 72 + 10 Binaan & Tim Adiwiyata Mandiri & Adiwiyata Mandiri \\
Nilai 72 & Tim Adiwiyata Nasional & Adiwiyata Nasional \\
Nilai 64 & Tim Adiwiyata Provinsi & Adiwiyata Provinsi \\
Nilai 56 & Tim Adiwiyata Kab./Kota & Adiwiyata Kab./Kota \\
Nilai Sekolah 0-80 & Tim Sekolah & Adiwiyata Sekolah \\
\hline
\end{tabular}

\section{Bagan 1.}

Tahapan Seleksi Penghargaan Adiwiyata

Sumber: KLH, 2013

Dari Bagan 1 terlihat bahwa Adiwiyata merupakan proses untuk membentuk karakter siswa yang cinta dan peduli terhadap lingkungan yang dimulai dari sekolah. Ada nilai-nilai yang harus dicapai sekolah untuk mendapatkan Penghargaan Adiwiyata sesuai tahapannya.

\section{Pelaksanaan Pendidikan Lingkungan Hidup di Kota Surabaya}

Kota Surabaya telah menerima penghargaan lingkungan terbanyak dibandingkan kota lain di Indonesia (Qodriyatun, 2019: 53). Keberhasilan tersebut tidak terlepas dari upaya Pemkot Surabaya melalui Dinas Lingkungan Hidup (DLH) Kota Surabaya yang sejak tahun 2007 berupaya menyukseskan Adiwiyata. Sudah lebih dari 25 sekolah mendapatkan Penghargaan Adiwiyata tingkat provinsi,
16 sekolah di tingkat nasional, dan hampir 20 sudah mendapatkan Adiwiyata Mandiri. Saat ini telah berpartisipasi sekitar 350 Sekolah Adiwiyata. Capaian tersebut sangat dipengaruhi peran serta warga dan Pemkot Surabaya yang bergotong-royong saling bahu-membahu demi terciptanya lingkungan yang diidam-idamkan.

Sebagai suatu proses, DLH mengadakan sosialisasi ke sekolahsekolah dengan informasi awal bahwa Adiwiyata adalah sebuah program dan bukan lomba sehingga tidak ada yang menang dan kalah. Hasil akhir Program Adiwiyata adalah perubahan perilaku, bukan piagam atau piala. Sekolah mengikuti Program Adiwiyata atas permohonan, bukan karena ditunjuk. Pemaham ini tidak menyurutkan keinginan sekolah di Kota Surabaya untuk ikut dalam 
Program Adiwiyata. Di beberapa tempat lain di Indonesia, sifat 'sukarela' dari Adiwiyata menyebabkan kurangnya minat sekolah untuk mengikuti proses Adiwiyata.

Selanjutnya berdasarkan Permen Adiwiyata, tahapan pertama bagi sekolah untuk terlibat dalam Program Adiwiyata adalah ketika sekolah mengikuti pembinaan Sekolah Adiwiyata. Tim Adiwiyata Sekolah dibentuk yang melakukan peninjauan mandiri atau asesmen diri sendiri terhadap lingkungan sekolah. Lingkungan yang dimaksud adalah kondisi sarpras sekolah. Permen Adiwiyata sudah menetapkan 33 implementasi kebijakan berwawasan lingkungan yang menjadi ciri Sekolah Adiwiyata. Jika keseluruhan implementasi kebijakan tersebut sudah memenuhi persyaratan nilai minimal 80 , maka sekolah dapat mengajukan usulan tertulis untuk mengikuti Seleksi Adiwiyata kepada Tim Kabupaten/Kota. Tim tersebut akan melakukan evaluasi administrasi dan melakukan kunjungan teknis ke Sekolah Adiwiyata. Jika semua persyaratan dan nilai yang diperoleh mencapai minimal 56 , maka Sekolah Adiwiyata akan mendapatkan Penghargaan Adiwiyata Kabupaten/Kota. Begitu seterusnya, Sekolah Adiwiyata menjalani proses implementasi PLH untuk meraih Penghargaan Adiwiyata Mandiri.

Mewujudkan Sekolah Adiwiyata yang mendapatkan penghargaan menjadi impian bagi semua sekolah yang ada di Kota Surabaya. Secara berkala DLH mengoordinasi pertemuan Sekolah Adiwiyata Mandiri dengan sekolah lain yang ingin menjadi Sekolah Adiwiyata (Mas'ad, 2019: 1). Hal ini memang menjadi persyaratan untuk mendapatkan Adiwiyata Mandiri karena Sekolah Adiwiyata Nasional harus melakukan pembinaan terhadap paling sedikit sepuluh sekolah lain yang telah mendapatkan Adiwiyata Kabupaten/ Kota. Selanjutnya, sekolah yang sudah menerima Penghargaan Adiwiyata Mandiri dapat diusulkan untuk ikut dalam seleksi penerimaan penghargaan tingkat regional, yaitu ASEAN Eco School.
Paparan Mas'ad (2019: 4-8) selaku Kepala SMP Al-Amin Surabaya yang mendapatkan Penghargaan Terbaik 1 Sekolah Adiwiyata Kota Surabaya Tahun 2019 mengindikasikan bahwa ada lima kiat untuk menjadi Sekolah Adiwiyata. Kelima kiat tersebut adalah: (1) komitmen seluruh warga sekolah; (2) dukungan dari berbagai pihak; (3) implementasi PLH dalam pembelajaran; (4) implementasi PLH dalam kegiatan ekstra kurikuler; dan (5) pembentukan karakter Adiwiyata yang memanfaatkan sumber daya alam yang tersedia dengan bijaksana. Kiat tersebut memperlihatkan adanya pemenuhan dari empat unsur Adiwiyata, yaitu kebijakan, kurikulum, partisipasi, dan sarpras.

DLH Kota Surabaya memberikan apresiasi kepada tiga peserta terbaik Sekolah Adiwiyata tingkat Kota Surabaya Tahun 2019 untuk SD dan SMP berupa trofi, sertifikat, dan uang pembinaan. Terbaik 1 mendapatkan uang pembinaan sebesar Rp15.000.000, terbaik 2 Rp12.500.000, dan terbaik 3 Rp10.000.000. Pemberian apresiasi ini dilakukan setelah DLH melaksanakan verifikasi dokumen dan lapangan kepada Calon Sekolah Adiwiyata Kota Surabaya Tahun 2019 di Bulan Januari 2019. Sekolah-sekolah yang diverifikasi merupakan sekolah binaan dari Calon Sekolah Adiwiyata Mandiri Tahun 2019, yaitu sekolah yang belum pernah mengikuti Program Adiwiyata. Sebanyak 21 sekolah yang merupakan binaan dari SMPN 12, SMPN 23 dan SMPN 41 yang mengikuti verifikasi ini, terdiri dari $17 \mathrm{SD}$ dan 4 SMP (DLH Kota Surabaya, 2019).

Pembentukan karakter yang menjadi inti dari PLH dilakukan melalui Program Adiwiyata dengan mengelola ruang terbuka hijau di sekolah, mulai dari pengelolaan kebersihan, penyediaan tempat sampah terpilah, komposting, sampai penghematan air maupun energi (Pemkot Surabaya, 2019: ii-247). Penanaman pohon dan perilaku budaya bersih sudah menjadi hal yang biasa bagi siswa SD, SMP, dan SMA di Kota Surabaya. Siswa 
menjadi agen peduli lingkungan dan bisa mengingatkan orang tua, untuk tidak sembarangan membuang sampah. Selain itu, siswa sudah terbiasa untuk membawa tumbler sendiri dan sekolah menyediakan air di galon-galon untuk isi ulang tumbler minuman (Qodriyatun, 2019: 53).

Sebagai agen peduli lingkungan, siswa SDK Santa Theresia 1 yang mendapatkan Penghargaan Adiwiyata Mandiri, pernah melakukan demonstrasi ke restoran cepat saji McDonald karena kemasan restoran pada waktu itu masih menggunakan stirofoam. Dalam demonstrasi, siswa membawa piring dan gelas sendiri, dan sejak saat itu McDonald mengadakan perubahan dan tidak lagi menggunakan stirofoam. Restoran cepat saji lainnya di Kota Surabaya juga mulai mengganti stirofoam dengan pembungkus yang lebih ramah lingkungan (Qodriyatun, 2019: 53).

Terkait sarpras, setelah Program Adiwiyata dilaksanakan telah terjadi penghematan penggunaan ATK, energi, dan air (Qodriyatun, 2019: 53). Sebagai apresiasi dari Pemkot Surabaya, sudah ada 22 sekolah yang mempunyai pembangkit listrik tenaga surya dengan kapasitas $120 \mathrm{~W}$ dan mampu digunakan selama 10 jam (Pemkot Surabaya, 2019: iv-22).

Praktik Adiwiyata disosialisasikan dalam berbagai event, misalnya peringatan hari lingkungan hidup. Mengadaptasi tema Beat Air Pollution untuk Hari Lingkungan Hidup Sedunia di tahun 2019, Pemerintah Indonesia melalui KLHK mengambil tema nasional yaitu "Biru Langitku, Hijau Bumiku" yang mengambil fokus pada penanganan emisi kendaraan dan memperketat konsentrasi parameter polusi udara. Di Kota Surabaya, rangkaian kegiatan peringatan Hari Lingkungan Hidup tersebut dilaksanakan selama tiga hari, yaitu mulai tanggal 26-28 Juli 2019, dengan kegiatan:

1) Kemah Hijau Sekolah Adiwiyata Provinsi Jawa Timur dengan peserta sebanyak 400 siswa dan guru pendamping dilaksanakan pada tanggal, 26-28 Juli 2019.

2) Pameran teknologi ramah lingkungan dengan peserta dari binaan industri/ perusahaan, Sekolah Adiwiyata, LSM/ PSI dan DLH Kabupaten/Kota di Jawa Timur, dilaksanakan pada tanggal 2728 Juli 2019.

3) Eco-Fest - festival lingkungan hidup, dengan kegiatan seperti sosialisasi/ education, mural competition, fashion show dan karnaval, serta fun walk dan bersih-bersih pantai bersama Gubernur Jawa Timur, dilaksanakan pada tanggal 28 Juli 2019.

Selain Adiwiyata, Pemkot Surabaya juga melaksanakan Surabaya Eco-School sejak tahun 2011 (Qodriyatun, 2019: 50). Tahun 2019, Surabaya Eco-School sudah memasuki tahun kesembilan dan sangat memotivasi sekolah untuk terlibat langsung dalam PLH. Tidak seperti Adiwiyata yang dilaksanakan setahun sekali penentuan capaiannya, eco-school dapat dilakukan dalam skala mingguan, bulanan, dan tahunan. Kriterianya juga tidak sampai kebijakan kurikulum, visi, misi, dan RPP sekolah, sehingga hampir semua sekolah dapat menerapkan eco-school.

Salah satu kegiatan eco-school yang selalu menjadi agenda adalah lomba yelyel lingkungan hidup yang memadukan lirik lagu, kostum daur ulang, alat musik daur ulang, dan gerakan seluruh anggota tim. Selain itu, ada juga penganugerahan terhadap individu, yaitu siswa, guru, dan kepala sekolah dari masing-masing jenjang pendidikan. Menurut DLH Kota Surabaya, anugerah diberikan dalam bentuk penghargaan dan jika ada perusahaan yang mensponsori kegiatan, maka ada bingkisan untuk individu dan bahkan sekolah yang mendapatkan anugerah. Tahun 2019, penerima Anugerah Sekolah Adiwiyata mendapat trofi, uang pembinaan, dan sertifikat.

Bersih-Bersih Pantai Kenjeran pada akhir pekan ketiga September juga 
menjadi agenda rutin. Dua tahun terakhir pelaksanaan Bersih-Bersih Pantai Kenjeran diikuti oleh lebih dari 15.000 orang relawan, termasuk para siswa. Acara ini merupakan salah satu upaya DLH Kota Surabaya dalam menggerakkan seluruh stakeholders yang peduli lingkungan untuk bersama menjaga lingkungan. Kegiatan ini dimulai dari siswa, tetapi tidak menutup kemungkinan pihak swasta yang berminat juga langsung turut terlibat di lapangan. Kegiatan ini menjadi model PLH tidak hanya untuk siswa dan sekolah, tetapi juga untuk seluruh warga.

DLH Kota Surabaya menyampaikan bahwa lomba jingle lingkungan hidup baru meramaikan Surabaya Eco-School sejak pelaksanaan tahun ketiga, yaitu tahun 2013. Jingle terbaik direkam di studio musik profesional agar dapat diperdengarkan di banyak tempat sebagai media kampanye lingkungan hidup. Beberapa kali dalam sehari, jingle tersebut diperdengarkan di persimpangan jalan raya, sehingga warga Kota Surabaya merasa terhibur dan pada saat yang bersamaan tertarik untuk menjaga lingkungan hidup setelah mendengarkan isi jingle dimaksud.

Selama tujuh tahun penyelenggaraan Surabaya Eco-School, tahun 2013 dan 2014 menjadi tahun yang terbaik, khususnya dalam penyediaan hadiah dari sponsor. Beragam hadiah untuk sekolah-sekolah terbaik diberikan, mulai dari instalasi pengolahan air limbah, penampungan air bekas wudhu dan rainwater tank atau tandon penampungan air hujan. Jika pada penyelenggaraan 2011, disediakan hadiah bagi individu terbaik berupa laptop dari ASUS, maka pada 2013 dan 2014, hadiah untuk individu terbaik adalah mengunjungi Australia Barat untuk program lingkungan hidup.

Pada pelaksanaan tahun 2016 dan 2017, Walikota Surabaya Tri Rismaharini menyediakan hadiah istimewa berupa tabungan masing-masing lima juta rupiah bagi sembilan individu terbaik dalam EcoPerson of the Year 2016. Sekolah-sekolah terbaik yang menang dalam Surabaya EcoSchool 2016 juga mendapat hadiah ekstra dari Walikota Surabaya, selain sarpras sekolah (Qodriyatun, 2019: 50).

\section{Penutup}

Pelaksanaan Program Adiwiyata di Kota Surabaya sudah sesuai dengan konsep PLH yang disepakati secara global. Para siswa di lembaga pendidikan negeri dan swasta, baik jenjang dasar, menengah, maupun tinggi, telah diperkenalkan dengan konsep PLH sejak Program Adiwiyata diperkenalkan. Masyarakat Kota Surabaya merupakan masyarakat yang aktif dan memiliki kesadaran tinggi dalam menjaga kelestarian lingkungan hidup. Walaupun tidak mengenal PLH sebagai sebutan umum untuk Program Adiwiyata, tetapi kegiatan PLH yang disepakati secara global sudah diinisiasi oleh dua program PLH yang ada di Kota Surabaya. Adiwiyata dan Surabaya Eco-School membawa perubahan positif kepada siswa, orang tua, dan masyarakat secara umum. Kondisi ideal ini diperkuat dengan komitmen Pemkot Surabaya yang mencanangkan pembangunan berkelanjutan sebagai salah satu program kerjanya.

Lima hal yang menjadi tujuan PLH bagi siswa dapat ditemui dalam program $\mathrm{PLH}$ di Kota Surabaya. Siswa memiliki kesadaran, pengetahuan, sikap, keterampilan, dan berpartisipasi aktif dalam masalah lingkungan. PLH di Kota Surabaya tidak lagi hanya tentang lingkungan, tetapi sudah menjadi pendidikan di/dari/melalui lingkungan, dan untuk lingkungan. Tetapi mungkin ada faktor penentu lain yang menyebabkan masyarakat Kota Surabaya sangat peduli terhadap lingkungan. Selain pemahaman yang ditanamkan melalui PLH, kepemimpinan di Pemkot Surabaya bahkan di Provinsi Jawa Timur sepertinya berperan besar dalam keberhasilan implementasi PLH. Sejak Adiwiyata 
dimulai, Jawa Timur selalu memimpin capaian proses dengan jumlah tertinggi dari total sekolah yang mendapatkan penghargaan. Sejak Walikota Surabaya terpilih di tahun 2010, dan saat ini hampir menyelesaikan periode kedua, gebrakan Surabaya Eco-School menjadi praktik baik tentang bagaimana PLH dapat dibuat lebih menarik dan dapat melibatkan lebih banyak sekolah tanpa harus menunggu waktu selama satu tahun.

Pemahaman yang dapat diambil dari UU Lingkungan Hidup adalah perlunya upaya mendorong kegiatan sekolah di bidang lingkungan hidup secara terstruktur dengan pendekatan kebijakan dan kurikulum yang melibatkan seluruh pihak dan membawa dampak pada lingkungan secara keseluruhan. Peran DPR adalah mengawasi jalannya penerapan UU Lingkungan hidup dan penerapan PLH yang berkesinambungan dan menyeluruh. Pemerintah provinsi/kabupaten/kota lain dapat belajar banyak dari PLH di Kota Surabaya. Sifat Program Adiwiyata yang sukarela dijawab dengan program Surabaya Eco-School yang lebih menarik dan dapat dengan cepat mengundang sekolah lain untuk mulai mengikuti proses Adiwiyata. PLH di Kota Surabaya sudah didukung kebijakan nasional, kebijakan daerah, sekolah, dan masyarakat dalam komunikasi baik antarsemua pihak.

\section{Daftar Pustaka}

Asaad, I. (2010). Toward Sustainable Indonesia Development. Dalam UNESCO, Education for Sustainable Development for Changing the Climate of Teacher Education to Address Sustainability. Jakarta: UNESCO.

Bhagwut, D. (1997). Environmental Education: An International Perspective. Aménagement et Nature, 127, 79-83.

Čeřovský, J. (2009). International Workshop on Environmental Education held at the 'Yugoslavia' Hotel, Belgrade, Yugoslavia, 13-22 Oktober 1975, Environmental
Conservation, 3(1), 76-77. doi: 10.1017/ S037689290001794X

Dinas Lingkungan Hidup [DLH] Kota Surabaya. (2019). Adiwiyata Kota Surabaya Tahun 2019. Diakses dari https://fdokumen. com/document/lh-adiwiyata-web-viewpemerintah-kota-surabaya-dalam-hal-inidinas-lingkungan.html.

Eneji, C. O., Akpo, D. M., \& Etim, E. (2017). Historical Groundwork of Environmental Education (Fundamentals and Foundation of Environmental Education). International Journal of Continuing Education and Development Studies, 3(1), 110-123.

Gough, A. \& Gough, N. (2010). Environmental education. Dalam C. Kridel (Ed.), The SAGE Encyclopedia of Curriculum Studies. New York: Sage Publications.

Greenschool. (2017). Early Years Curriculum Overview. Bali: Greenschool Bali Indonesia.

Ivanova, M. (2010). UNEP in Global Environmental Governance: Design, Leadership, Location. Global Environmental Politics, 10(1), 30-59.

Jayadinata, A. K. (2017). Pengembangan Pendidikan Lingkungan Hidup melalui Science Technology Society pada Pendidikan Nilai Kesadaran Lingkungan. Makalah dalam Prosiding Seminar Nasional "Membangun Generasi Emas 2045 yang Berkarakter dan Melek IT" dan Pelatihan "Berpikir Suprarasional". J. Julia, I. Isrok'atun, I. Safari (Eds.). Sumedang: UPI. 460-470.

Kementerian Lingkungan Hidup [KLH]. (2011). Panduan Adiwiyata Sekolah Peduli dan Berbudaya Lingkungan. Jakarta: Kementerian Lingkungan Hidup.

Kementerian Lingkungan Hidup [KLH]. (2013). Peraturan Menteri Lingkungan Hidup Republik Indonesia Nomor 05 Tahun 2013 tentang Pedoman Pelaksanaan Program Adiwiyata.

Kementerian Lingkungan Hidup dan Kehutanan [KLHK]. (2019). Statistik Lingkungan Hidup dan Kehutanan Tahun 2018. Jakarta: KLHK.

Komisi Nasional Indonesia untuk UNESCO [KNIU]. (2014). Pendidikan untuk 
Pembangunan Berkelanjutan di Indonesia. Implementasi dan Kisah Sukses. Jakarta: Kemendikbud.

Marco, R., Mindt, L., \& Gardiner, S. (2017). Education for Sustainable Development Goals. Learning Objectives. Paris: UNESCO.

Mas'ad, M. (2019). Kiat-kiat Menuju Sekolah Adiwiyata Kota Surabaya. Presentasi Terbaik 1 Sekolah Adiwiyata Kota Surabaya Tahun 2019. Verifikasi Penilaian Sekolah Peduli dan Berbudaya Lingkungan (Adiwiyata) Kota Surabaya tahun 2019.

Mishra, P. K. (2017). Environmental Education as a Driver for Sustainable Development Goals. Dalam S. Sahdev \& M. Kumar (Eds.). Environment and Sustainable Development: A Geographical Appraisal. New Delhi: Concept Publishing Company Pvt. Ltd.

Mohamed, E., Kidundo, M., Tagelseed, M. (2006). Environmental Education and Public Awareness. Workshop Paper. Post Conflict National Plan for Environmental Management in Sudan, Khartoum, Juli, 18-20, 2006.

Pemerintah Kota [Pemkot] Surabaya. (2019). Buku Laporan Dokumen Informasi Kinerja Pengelolaan Lingkungan Hidup Daerah (DIKPLHD) Kota Surabaya Tahun 2018. Surabaya: Pemkot Surabaya.

Prasetyo, K. \& Hariyanto. (2017). Pendidikan Lingkungan Indonesia, Dasar Pedagogi dan Metodologi. Bandung: Remaja Rosdakarya.

Pruitt, A. (2019). Principles and Practices of Education. Essex: ED-Tech Press.

Qodriyatun, S. N. (Ed.). (2019). Sampah Plastik dan Implikasi Kebijakan Pembatasan Plastik Sekali Pakai terhadap Industri dan Masyarakat. Malang: Intrans Publishing.

Sand, P. H. (2015). The History and Origin of International Environmental Law: Introduction. Cheltenham: Edward Elgar Publishing Ltd.

Sekarwinahyu, M. (2008). Sejarah dan Konsep Dasar Pendidikan Lingkungan Hidup. Dalam M. Rumanta, G. Nurdin, T. Wahyuningsih, A. Ratnaningsih, K. Iryani, \& M. Sekarwinahyu. Pendidikan Lingkungan
Hidup. Tangerang Selatan: Universitas Terbuka. Diakses dari http://repository. ut.ac.id/4264/2/PEBI4223-M1.pdf.

Sohn, L. B. (1973). The Stockholm Declaration on the Human Environment. The Harvard International Law Journal, 14(3), 423-515.

Ulul Albab, H. A. (2017). Memahami Pendidikan Agama Islam melalui Program Adiwiyata (Cinta Lingkungan) di SMP Negeri 2 Lamongan. JALIE, Journal of Applied Linguistics and Islamic Education, 01(02), 254-271.

UNESCO. (2014). Shaping the Future We Want. UN Decade of Education for Sustainable Development (2005-2014). Final Report. Paris: UNESCO.

United Nations [UN]. (2015). Transforming Our World: The 2030 Agenda for Sustainable Development. A/RES/70/1. Diakses dari https://sustainabledevelopment.un.org/ content/documents/21252030\%20 Agenda $\% 20$ for $\% 20$ Sustainable $\% 20$ Development\%20web.pdf.

United Nations Environment Programme [UNEP]. (1972). Declaration of the United Nations Conference on the Human Environment. Diakses dari https://www. ipcc.ch/apps/njlite/srex/njlite_download. php?id=6471.

Yustina. (2006). Hubungan Pengetahuan Lingkungan Hidup dengan Persepsi, Sikap dan Minat dalam Pengelolaan Lingkungan Hidup pada Guru Sekolah Dasar di Kota Pekanbaru. Jurnal Biogenisis, 2(2), 67-71. 